\title{
A viselkedési pénzügyek és a fogyasztói kölcsönszerződések*
}

\author{
Fömötör Barna - Parádi-Dolgos Anett - Sipiczki Zoltán
}

\begin{abstract}
A lakossági hitelezési tevékenység során, különösen a devizahitelezéssel kapcsolatban kialakult helyzet miatt minden olyan körülményt figyelembe kell venni nevezetesen a fogyasztói önkontroll hiányát, az alul- és túlreagálásokat, valamint a lakossági fogyasztók intertemporális döntéseire visszavezethető kockázatokat-, amelyek túlzott, rendszerszintü kockázatok kialakulásához vezethetnek. A szerzők a torzított időközi modellek elemzésével kívánják érthetővé tenni a fogyasztói döntéseket. A releváns szakirodalomra támaszkodva, viselkedéstudományi megközelítésben világítanak rá a cselekvés vagy éppen a passzivitás hátterére, a fogyasztói racionalitást torzító tényezőkre és az ebből eredő problémák lehetséges kezelésére, különös tekintettel az eszközszabályozásra és a fair bank törvényekre, a jogviszonyok mélyebb és átfogóbb szabályozására, s szem előtt tartva nemcsak a fogyasztók védelméhez füződő kiemelkedő érdeket, hanem a pénzügyi intézmények hosszú távú, kiszámitható és fenntartható müködését is.
\end{abstract}

Journal of Economic Literature (JEL) kódok: D18, D90, L15

Kulcsszavak: lakossági eladósodás, intertemporális döntések, rendszerkockázat, szabályozás

\section{Bevezetés}

A fogyasztók fogyasztással kapcsolatos döntéseiket számos esetben nem racionális alapon, hanem intertemporális választási modellekkel leírhatóan, alul- és túlreagálásokkal kísérve hozzák meg. A termékeket és szolgáltatásokat nyújtó szervezetek gyakran ismerik, és akár kihasználják ezeket a döntési aszimmetriákat. A megszerzett tudást felhasználva fejlesztenek termékeket, kínálnak szolgáltatásokat a fogyasztóknak. Különösen hangsúlyos a szerepe a pénzügyi közvetítőrendszer szereplőinek, akik a kívánt fogyasztáshoz szükséges forrás rendelkezésre bocsátásában játszanak

* Jelen cikk a szerző nézeteit tartalmazza, és nem feltétlenül tükrözi a Magyar Nemzeti Bank hivatalos álláspontját.

Fömötör Barna a Magyar Nemzeti Bank föigazgatója. E-mail: foigazgato.titkarsag@mnb.hu. Parádi-Dolgos Anett a Kaposvári Egyetem egyetemi docense. E-mail: dolgos.anett@ke.hu.

Sipiczki Zoltán a Kaposvári Egyetem és a Pallas Athéné Domus Scientiae Alapítvány PhD-hallgatója.

E-mail: sipiczki.zoltan@ke.hu.

A kézirat első változata 2016. augusztus 15-én érkezett szerkesztőségünkbe.

DOI: http://doi.org/10.25201/HSZ.16.2.154167 
főszerepet, meghatározva ezáltal a jövőbeni fogyasztást. A téma vizsgálatának a jelentőségét tehát nem lehet kellőképpen hangsúlyozni.

A vállalkozások, de különösen és kiemelten a pénzügyi intézmények - ismerve a fogyasztói viselkedés fontosabb mozgatórugóit, motivációit - a nagyobb profit gyorsabb megszerzése érdekében felerősítik, katalizálják a döntési folyamatot. Ezzel a magatartással szükségképpen a torz, nem racionális döntési folyamatot erősítik, a rövid távon elérhető előnyökre fókuszálva és figyelmen kívül hagyva a közép- és hosszú távon jelentkező hátrányokat, negatív következményeket. (Paradox módon a pénzügyi intézmények menedzsmentje és tulajdonosai ezirányú viselkedésének alapvető jellemzői megegyeznek az irracionális fogyasztói viselkedéssel.) Ezt a folyamatot további erősíti az információs aszimmetria, valamint a fogyasztói türelmetlenség. A téma szempontjából tehát szükségszerű elsőképpen elemezni a torzított időközi modelleket, ezek használatával érthetővé válnak a fogyasztói döntések. A feltárt okok és motivációk megértésével kerülhetünk közelebb a probléma megoldásához. A viselkedéstudományi megközelítésen keresztül megérthetjük a cselekvés vagy éppen passzivitás hátterét.

\section{Intertemporális döntések története és a diszkontált hasznossági modell}

Az intertemporális döntéseket 1930-ban Fischer (1930) modellezte először, aki szerint több különböző időpont jelenbeli hasznosságérzésének összehasonlítása az időpontokhoz kapcsolódó helyettesítési határrátától függ. A helyettesítési határrátát az időpreferencia és a csökkenő határhasznosság határozza meg. A területen jelentős előrelépést a Paul Anthony Samuelson által megalkotott diszkontált hasznossági modell jelentett, mely gyorsan elterjedt és nagy népszerüségre tett szert, elsősorban egyszerűsége miatt, mivel a döntést befolyásoló számos, heterogén és szerteágazó (pszichológiai) tényezőt egyetlen paraméterbe, a diszkontrátába sürítette bele, és ezt a diszkontrátát konstansnak tekintette. Ez alapján a különböző időpontokban jelentkező hasznosságok könnyedén összehasonlíthatóvá váltak. Samuelson (1937:156) így fogalmazott: ,,az egyén viselkedése bármely tetszőleges időszak alatt arra irányul, hogy megfelelő időbeli diszkontálással maximalizálja az összes jövőbeli hasznosságnak azonos nagyságrendűvé csökkentett összegét. Az egyén a jövőbeli hasznosságokat egyszerű és következetes módon számítolja le, mely módszer ismert számunkra." A modellhez tehát pozitív idődiszkontálási mértéket kell társítani, azaz egy jövőben távolabbi időpont mindig kisebb hasznosságérzéssel fog jelentkezni, így a jelenhez közelebbi fogyasztást fogja erősíteni. A diszkontált hasznossági modell a diszkontfaktort exponenciális módon kezeli, azaz (idő)egységenként állandó módon fog változni a jelenben és a jövőbeni fogyasztáshoz kapcsolódó hasznosságérzés aránya. A diszkontált hasznossági modellt tehát konstans diszkontráta és időkonzisztens preferencia jellemzi (Bölcskei 2009). 


\subsection{Jelen felé torzított preferenciákat leíró hiperbolikus és kvázi hiperbolikus modellek}

Nem véletlen, hogy az előzőekben bemutatott feltételrendszert egyre többen vonták kétségbe, támadták. A konstans diszkontráta és az időben konzisztens preferencia életszerútlenül szabályosnak, már-már normaszerūnek tűnt, amellyel kapcsolatban empirikus kutatások vezettek a modellt kétségbe vonó eredményekre. A viselkedési közgazdaságtan keretében végzett számos kísérlet azonban cáfolta a diszkontált hasznossági modellt. Ezek eredményeként az is egyértelmúvé vált, hogy a résztvevők viselkedése más diszkontálási modellel jobban leírható. A további kutatások eredményeként kialakultak a jelen felé torzított preferenciákat leíró, hiperbolikus és kvázi hiperbolikus modellek.

A modell módosítására több alkalommal is sor került, míg végül Loewenstein és Prelec 1992-ben megalkotta az általánosított hiperbolikus diszkontálást, amely már alkalmas volt számos korábbi anomália kezelésére, az emberi viselkedés általánosabb leírására. Összetettebb modellekben azonban már nehezen volt alkalmazható (Neszveda-Dezső 2012).

A kvázi hiperbolikus diszkontálás alapgondolata Phelps és Pollak (1968) nevéhez füződik. Lényege, hogy az időszakokhoz rendelhető diszkontráta az időszakok közötti választás esetében inkonzisztens, a rövid távú időpreferenciához nagyobb diszkontrátát rendel. Összehasonlítva a kvázi hiperbolikus diszkontálás is a hiperbolikus diszkontáláshoz hasonló időben inkonzisztens viselkedést ír le, azonban a modell egyszerűbb és könnyebben kezelhető, mint a hiperbolikus diszkontálási modellek (Nagy 2011).

\subsection{A hiperbolikus és a kvázi hiperbolikus modellek jelentősége, alkalmazhatósága}

„A hiperbolikus és kvázi hiperbolikus modellek jelentősége elsősorban azzal fogható meg, hogy általuk leírhatóvá, megmagyarázhatóvá váltak korábban értelmezhetetlen emberi viselkedések" (Bölcskei 2009:1027). A jelen felé torzított preferenciának köszönhetően ugyanis a jelenkori fogyasztáshoz kapcsolódó hasznosságérzés nagyobb súlyt képvisel, mint a jövőben esedékes fogyasztáshoz társuló hasznosságérzés. A neoklasszikus keretben alkalmazott exponenciális diszkontálásból is következik, hogy a jelenkori fogyasztás hasznossága nagyobb, mint bármelyik későbbi időpont fogyasztásához tartozó hasznosság. A jövőbeni fogyasztás minél későbbi időpontra „csúsztatása” viszont nem exponenciális jelleggel, hanem annál nagyobb mértékben csökkenti az ahhoz kapcsolódó hasznosságot. Erre tekintettel az egyén abban lesz érdekelt, hogy teljeskörűen, sőt akár a jelenbeli anyagi elehetőségeit meghaladó módon törekedjen fogyasztásának, pontosabban az ahhoz kapcsolódó hasznosságérzésének a maximalizálására. Ez utóbbi azonban számos egyéb tényezőtől is függ, így a fogyasztási határhaszon alakulása, a diszkontráták nagysága, a jövőbeni 
jövedelem várt alakulása és a hitelkamat mértéke együttesen határozza meg, hogy hitelfelvételre sor kerül-e vagy sem.

A hiperbolikus diszkontálási modell az önkontrollproblémákra vonatkozó vizsgálatok népszerű alkalmazási területe lett. De miért is használhatók jól a hiperbolikus modellek az önkontrollproblémák leírására? Az önkontroll a hagyományos, racionalitásra épülő neoklasszikus közgazdaságtan alapvető feltételezése a fogyasztóval szemben. A racionális fogyasztók például képesek hasznosságuk szerint rangsorolni Neumann és Morgenstern (1953) racionalitási rendszere szerint is. A fogyasztó tehát megfelelö önkontrollal rendelkezik, azaz nem fog irracionális döntéseket hozni, éppen azért, mert kontrollálja magát. A probléma ezzel az, hogy a valóságban a fogyasztók számos esetben hoznak irracionális döntéseket, amelyeket a hagyományos közgazdaságtan nem tud megfelelően megmagyarázni.

A valósághoz való közelítéshez nyújt eszközt az önkontrollprobléma felvetése. Önkontrollproblémás egyén esetében ugyanis már ezzel magyarázható a racionálistól való eltérés. Ezt modellezték többen is, így például Camerer és társai (1997) New York taxivezetőit vizsgáló tanulmányukban arra jutottak, hogy múködésüket és munkaidejük hosszát gyakran heurisztikus döntések alapán határozzák meg. Szerintük a pszichológiában gyökerező adaptív modellek jobb előrejelző-képességűek olyan esetben, amikor a vizsgált területre az emberi döntések is hatással vannak. Ennek megfelelően a hiperbolikus modellek már képesek megfelelően kezelni a helyzetet: ha a preferenciáinkat megtestesítő vágyakat nem tudjuk kontroll alatt tartani, akkor a preferenciánk automatikusan eltolódik időben a jelen felé, mihamarabb teljesíteni akarjuk, ki szeretnénk élni a vágyainkat. A viselkedési pénzügyek matematikai formalizálását - melyre terjedelemi korlátok miatt nem térünk ki - tovább nehezíti, hogy a döntések nem egy-, hanem többperiódusosak, amelyekre nagy hatással van a kockázat és a bizonytalanság (Merton 1969).

Összességében a hiperbolikus modellek alapján a jelenben lévő jóléti hasznosság mindig jóval magasabb, mint a jövőbeni, erre tekintettel sokkal vonzóbb a jelenkori, hirtelen nyereség, és sokkal fájóbb az azonnali költség, mint a később bekövetkező.

\section{Viselkedési közgazdaságtani megállapítások, intertemporális modellek alkalmazása a pénzügyi szektorban}

A fogyasztói hitelek „jogilag szabályozott” keretek közé szorítása - ideértve a kikényszeríthetőség, érvényesíthetőség jogszabályi keretek közé szorítását is - a 20. század elejére tehető. Tekintettel arra, hogy nemzetgazdasági jelenőségük - a fogyasztásra gyakorolt hatásuk következtében - egyre inkább nőtt, elkerülhetetlenné vált a széles körben történő elterjedésük. Ez a folyamat magával hozta a nem megfelelő hitelezési gyakorlat kialakulását és túlburjánzását, ami a korábbi időszakokat is jelentősen meghaladó káros társadalmi következményekhez vezetett. 
Vegyük figyelembe, hogy a jelen-jövő csere „visszafele” is múködik, azaz az egyén kölcsönfelvétel útján, jövőbeni fogyasztása elcserélésével juthat a jelenlegi pénzügyi lehetőségeit meghaladó többletfogyasztáshoz, a jelen felé torzító, inkonzisztens időpreferencia következtében. A fogyasztók előzőekben bemutatott időinkonzisztens viselkedése nem újdonság a banki hitelezés területén.

A hazánkban egyre jobban ismert és egyre több fogyasztó által használt hitelkártyákkal mint a fogyasztói hitelek egyik tipikus formájával, megjelenési módjával kapcsolatban széleskörű kutatásokat végeztek, lényegesebb megállapításaikat az alábbiakban mutatjuk be.

Laibson - Repetto - Tobacman (2003) arról számol be, hogy az Egyesült Államokban a hitelkártya-adósság aránya kiemelkedően magas, ami arra utal, hogy a fogyasztók sok hitelt vesznek fel magas költségen. Ez a folyamat már önmagában hordoz irracionális elemeket, hiszen a hitelkártya-adósság költségei jóval magasabbak, mint a pénzpiaci kamatok. A kutatás arra is rámutatott, hogy jelentős a hosszú távú, de facto illikvid megtakarítások aránya is, amely körülmény hiperbolikus diszkontálású preferenciát feltételez, és alapvetően vonja kétségbe az exponenciális diszkontálás lehetőségét. A tanulmányban lehetséges magyarázatként jelenik meg a fogyasztók naivitása. Mostanra a fogyasztói túlreagálás klasszikus példájának minősíthetnénk Ausubel (1999) akkoriban újdonságnak minősülő kutatásában bemutatott esetkört. A kutatás szerint a hitelkártyát kérelmezők nem képesek még megközelítőleg pontosan sem megbecsülni hitelkártyájuk jövőbeni egyenlegét, kisebb vagy sokkal kisebb hitelösszeg igénybevételével számolnak. Nem jól mérik fel ugyanis a bevezetési időszak során nagyon alacsony kamattal kínált hitelt, majd mikor ez az "akciós” időszak véget ér, addigra a már jóval magasabb kamatok mellett jelentősen túlvállalt összegú visszatérítést kell fizetniük. Ebben az esetben tehát a fogyasztók alulbecsülik a jövőben ténylegesen igénybe vett hitel összegét, ezzel együtt túlreagálják a bevezetőnek szánt alacsony kamat kedvező mivoltát. Az alul-, illetve túlreagálás mellett Ausubel (1999) felhívta a figyelmet kontraszelekciós jelenségre is, nevezetesen, ha a fogyasztó igénybe vette a bevezető időszaki törlesztőrészlettel adott hitelfeltételeket, akkor hajlamos lesz nagyobb hitelösszeget felvenni. Ez a megállapítás egyben jelzi a viselkedés kockázatát a hitelnyújtónak is, mivel az ilyen ügyfelek jóval kockázatosabbak. Összességében a kutatás eredménye közvetve rámutathat a morális kockázat kialakulásához. A hitelt nyújtó pénzügyi vállalkozás tudja, hogy akciós ajánlataikkal olyan ügyfélállományt tudnak felépíteni, amelyben egyre több és egyre magasabb kockázatú fogyasztó jelenik meg. Az ilyen folyamat tehát rossz minőségű hitelállomány felépítéséhez vezethet.

Stango és Zinman (2009) a klasszikus vásárlási hitelek tanulmányozása során alapvető problémaként azonosította, hogy a fogyasztók a képzetlenségük miatt nem képesek megítélni az ajánlatok valódi költségét. Mivel erre nem képesek - szellemi képességeik, illetőlege a pénzügyi képzettség hiányában - könnyedén elfogadják 
a számukra rosszabb, hátrányosabb ajánlatokat. A kutatás kitért továbbá arra, hogy a fogyasztók megfelelő informálása nem változtatott a helyzeten, továbbá a piaci verseny sem oldotta meg a problémát. A drágább szolgáltatást igénybe vevő fogyasztókból épített állomány ugyan rövid távon jövedelmezőbb, közép- vagy hosszú távon azonban hitelezési kockázat kialakulásához vezet.

Az előzőek lényegét Koltay és Vincze (2009) az alábbiak szerint foglalta össze: „Az okok között leggyakrabban a nem exponenciális diszkontálást, a naivitást, illetve a túlzott önbizalmat szokás megemlíteni, továbbá az olyan kognitív hibákat, mint a matematikai és pénzügyi számítások elvégzésére való képtelenség, illetve a döntési helyzet objektív megfogalmazásának hibái. A hiperbolikus (nem exponenciális) diszkontálás naivitás, a túlzott önbizalom kérdésében a bizonyítékok inkább közvetettek, a viselkedés jellemzésére ezeknek a hipotéziseknek az együttese, úgy túnik, alkalmasabb, mint az exponenciális diszkontálás és a teljes racionalitás felvetése." (Koltay - Vincze 2009:513). A bankok ugyanis számos olyan termékkel szolgálnak a lakosságnak, amelyek kifejezetten a jelen felé torzult időpreferenciát használják ki. Sebestyén és tórsai (2011) tanulmánya vitatja, hogy a dinamikusan időinkonzisztens preferenciáknak kritikus szerepe lett volna a probléma kialakulásában, de szerintük is a mai magyar hitelezési gyakorlatban elterjedt hitelezési módszernek minősülnek az elengedett up-front díjak, valamint az első időszak(ok) akciós kamatai. Mostanra szinte széles körben ismert és a fogyasztók körében elfogadott termékké váltak az olyan fogyasztói hitelek, amelyeket az első türelmi időszakban nem kell törleszteni. Különösen csábítóak ezek az ajánlatok a vásárlás szempontjából frekventált időszakban, például ünnepek előtt. Az időben inkonzisztens, jelen felé torzuló pozitív időpreferencia jellemzőire építenek azok a banki ajánlatok, amelyek a kedvezményes törlesztésű vagy törlesztésmentes időszak mellett vagy helyett a kölcsönöszszeg mielőbbi igénybevételét kínálják. Szintén az intertemporális döntési torzítást használják ki az ún. előre kifizetett betétikamat-konstrukciók, amikor a hitelintézet az elhelyezett betét után járó kamatokat a betét elhelyezésének időpontjában jóváírta az ügyfél számláján, így az érintett a kamat összegéhez a betéti futamidő elején hozzájut, azt egyből felhasználhatja, elfogyaszthatja, tulajdonképpen a bank meghitelezte a betéti kamatot.

A banki hitelezési gyakorlat könnyen vezethet (és vezetett) olyan fogyasztói hitelfelvételhez, ahol az adós az inkonzisztens időpreferenciája, a jövőbeni anyagi helyzetét érintő optimista, túlzottan magabiztos becslése következtében olyan hitelt vett fel, amelynek törlesztőrészleteit nem volt képes teljesíteni. Az ilyen hitelezési gyakorlat kialakulásában közrehatott a pénzügyi közvetítők információs erőfölénye is. Információs előny helyett pontosabb és szakszerúbb információs aszimmetriára hivatkozni, mivel a banki termékek és szolgáltatások szinte minden esetben olyan speciális szaktudást igényelnek, amelyek az ügyfelek meghatározó részéről teljeskörűen hiányoznak, vagy csak nyomokban vannak jelen. Ez utóbbi körülmény meg- 
felelő szakmai háttértudás és általános szakmai ismeretek hiányában sajnos még súlyosabb következményekhez vezethet, mint a szakmai ismeretek teljes hiánya.

A téma teljeskörü feltárása érdekében célszerủ kitérni még a fogyasztói türelmetlenség esetére is. Fogyasztói türelmetlenség alakul ki, ha a fogyasztási cikkekről hoszszabb-rövidebb időre kénytelenek vagyunk lemondani, vásárlásainkat elhalasztani. „A fogyasztási cikkekről történő ideiglenes lemondás okának megszűnését követően a fogyasztói türelmetlenség miatt az elhalasztott fogyasztás bepótolására kerül sor. \|lyenkor jóval magasabb a fogyasztási határhajlandóság" (Tóth - Árvai 2001:1024).

Bár a fenti viselkedésminták egyedileg is károsak, ha a társadalom nagy arányát érintik, jelentős makrogazdasági károkat okozhatnak. „A társadalom pénzügyi ismereteinek területén olyan súlyos hiányosságok mutatkoznak, amelyek a ciklikus gazdasági válságok idején akadályozzák a helyreállítást és a konszolidációt" (Kovács 2015:87).

Az eseti példákkal és a szakirodalom megállapításaival összhangban megállapítható, hogy az érintett fogyasztói döntések okai viselkedési közgazdaságtani jellegűek. A fogyasztói döntések irracionális, viselkedési közgazdaságtan által feltárt okai tehát: a jelen felé torzuló, pozitiv (idő)preferencia, a túlzott optimizmus, túlzott elbizakodottság, az információs aszimmetria, információfeldolgozási hiányosságok. Az így kialakuló és egyre súlyosbodó probléma életre hívja az optimális megoldási lehetőségek számba vételét. A lehetséges megoldások közül az általunk leghatékonyabbnak tartott a szabályozás mint olyan.

\section{A probléma létrejötte és eszkalálódása}

A probléma és az arra adott szabályozói megoldás megértése céljából indokolt röviden áttekinteni a Magyarországon kialakult devizaalapú hitelezés fontosabb jellemzőit, továbbá a 2015-ös szabályozást megelőző helyzetet, amely körülmények végül a szabályozás megalkotásához vezettek.

„A túlzott növekedési hajsza következtében a hazai bankrendszer - zömében az anyabankokon keresztül - jelentős mértékben vont be külföldi forrást. Ennek eredményeként a hazai bankszektor nemzetközi mértékben is erősen ráutalttá vált a rövid devizaforrásokra, a hitel/betét arány a régió más országaihoz képest is nagyon megnőtt, messze eltávolodott az egészségesnek tekinthető, 100 százalék körüli értéktől. Az olcsó külföldi források így növelték a kockázatvállalási hajlandóságot és táplálták a prociklikus hitelezést" (Bethlendi 2015:21).

Devizaalapú hitelezés esetén a pénzintézet a saját országának pénznemében ${ }^{1}$ folyósítja a hitelt, a hiteladós pedig szintén ebben a pénznemben fizeti vissza a banknak

\footnotetext{
${ }^{1}$ vagyis ahol a fiók telephelye található
} 
mind a tőke-, mind pedig a kamattartozását, azonban a kölcsön összegét devizában tartják nyilván, vagy devizában folyósítják (a kirovó pénzneme deviza), és a törlesztés forintban történik (azaz a lerovó pénznem forint). Az átváltás a szerződésben rögzítetteknek megfelelően a folyósítás és a törlesztés időpontjában érvényes árfolyamon történik.

A deviza alapú hitelezéssel több alapvető probléma volt, mivel a kölcsönt forintban folyósították és fizették is vissza, de a kölcsönt devizában tartották nyilván, így valójában a fogyasztó magára vállalta a teljes árfolyamkockázatot. „Akik devizahitelt vettek fel, vállalták az esetleges árfolyamnyereséget és veszteséget. Jogot és kötelezettséget szereztek a devizapiacon - még ha ez nem is állt szándékukban. A svájci frank minden forintnyi erősödése az ő nyereségükké vált - amint a forint gyengülése a veszteségükké. Ez utóbbit el lehetett volna kerülni egyfajta árfolyam-biztosítással, de nem vásároltak maguknak devizavételi jogot, nem vettek határidőre devizát. Ha ez utóbbit teszik, akkor pont elvesztették volna a kamatkülönbözetet" (Száz 2015:82). Ez az esetek meghatározó részében hosszú távra történt, amely időtávon nyilvánvalóan lehetetlen devizapárok árfolyamát modellezni, azaz a devizaalapú hitelezés valójában egy fel nem mérhető, ebből adódóan rendkívül magas kockázatú termék volt.

A hitelfelvételek egy részénél közrejátszhatott az a racionális fogyasztói eurozóna-csatlakozással kapcsolatos várakozás, adaptív árfolyam-várakozás, ami a válság előtt a hitelfelvétel pillanatában visszatekintve stabilnak bizonyuló forintárfolyam következtében érthető módon alakulhatott ki a lakosság körében (Kolozsi - Banai - Vonnák 2015). De gyakran ügyfeleket, akik a forinthitelnél nem voltak hitelképesek, az alacsonyabb kamatozású devizahiteleknél már hitelképesnek nyilvánították, figyelmen kívül hagyva az árfolyamkockázatot (Bánfi 2013). „A devizahitelt felvevő magyar háztartások jelentős része hazai valutában hitelképtelen volt (lett volna), ezért nem is kaptak forinthitelt. Ezt már csak annyival kell kiegészíteni, hogy természetesen nincs olyan tartós banktechnikai megoldás, amivel a hitelképtelen ügyfél hitelképessé válhatna - különösen nem azáltal, hogy a hitel devizaneme megváltozik" (Lentner 2015:311). Elterjedésének oka, hogy kedvezőbb törlesztőrészlettel lehetett igénybe venni, mint a forintalapú hiteleket, viszont az előzőek szerint a fogyasztó egy felmérhetetlen kockázatot is vállalt, amellyel nagy valószínűséggel nem törődött, nem is ismerte meg, és nem is volt képes megérteni a kockázat okát. Pedig „a háztartásokkal szemben a bankszektornak lényegesen szélesebb eszköztár áll rendelkezésére a lakosság számára nyújtott devizahitelekből fakadó kockázatok kezelésére" (Kolozsi-Banai - Vonnák 2015:61).

Sajnos azt kell mondanunk, hogy a devizaalapú hitelezésnél „jobb” példát nem is találhatunk az előző részben bemutatott viselkedési közgazdaságtani problémák, a torzított időközi döntések, az alul- és túlértékelés érzékeltetésére. 


\section{Etikus banktörvény}

A fogyasztónak nyújtott hitelről szóló 2009. évi CLXII. törvény és egyes kapcsolódó törvények módosításáról szóló 2014. évi LXXVIII. törvény (továbbiakban Fhtv.) „fair”, azaz etikus bankrendszer néven vált ismertté, amely átláthatóvá és követhetővé teszi a fogyasztói hitelszerződések kamatának alakulását. A jogszabályok vonatkozó előírásait 2015. február 1. napjától kell alkalmazni. „A központi banki feladatok kiterjesztését a jogalkotók világszerte megtették. Maguk a központi bankok döntéshozói is átértékelték intézményeik gazdasági szerepvállalását. A központi bankok gazdasági felelősségét a változások hatására úgy értelmezhetjük, hogy a központi bankoknak érzékenyebbnek kell lenniük a gazdasági folyamatok társadalmi hatásaira" (Lentner - Szegedi - Tatay 2015:39).

A Magyar Nemzeti Bank adatai szerint „a fogyasztási hitelek volumene az eddigi legmagasabb szintet 2010. június 30-án érte el, amikor is összesített értékük meghaladta a 8647,9 milliárd forintot. Ez az érték 2014-ig folyamatosan csökkent, de a fogyasztói hitelek volumene 2014. június 30-án még mindig meghaladta a 6802 milliárd forintot. Ebből 3139,1 milliárd forint a forint alapú fogyasztói hitelek értéke, 3662,9 milliárd forint pedig a devizahitelek nagysága. Mindezek alapján a hitelszerződések jogán belül a fogyasztóvédelem szintjének emelése érdekében a jogalkotó az Fhtv. módosítására irányuló törvényjavaslatot dolgozott ki."2

\subsection{A legfontosabb módosítások}

A fogyasztónak nyújtott hitelről szóló 2009. évi CLXII. törvény és egyes kapcsolódó törvények módosításáról szóló 2014. évi LXXVIII. törvény az alábbi főbb kérdéseket érinti:

\subsubsection{Szerződést megelőző tájékoztatási kötelezettség hatékonyabbá tétele}

A racionális fogyasztók keretrendszere nem csak azt jelenti, hogy az információt helyesen értelmezzék, az is szükséges, hogy legyen elegendő információjuk következtetéseik helyességéhez (Barberis - Thaler 2003).

Fontos tehát, hogy a kölcsönszerződések megkötése előtt pontos és elégséges információt kapjanak a szereplők. Sőt szükséges feltétel, hogy a szerződések szövege korábban megismerhető legyen. A Nobel díjas Daniel Kahneman és Amos Tversky (1974) kutatása alapján a bonyolult és kockázatos döntési helyzetekben a szereplők gyakran leegyszerűsítik a problémát és korábbi részinformációik, szubjektív érzéseik, előítéleteik és ökölszabályok alapján hozzák meg döntéseiket racionális elemzés helyett.

\footnotetext{
2 Törvényi indokolás: A fogyasztónak nyújtott hitelről szóló 2009. évi CLXII. törvény és egyes kapcsolódó törvények módosításáról szóló 2014. évi LXXVIII. törvény
} 
Azért, hogy hatékonyabb és racionálisabb döntéseket hozzanak a szereplők, a törvény kimondja, hogy a szerződéskötést megelőzően a hitelező és a hitelközvetítő köteles felvilágosítást adni. Ezáltal a fogyasztó felmérhesse a felvenni kívánt hitel megfelel-e az igényeinek, illetve a pénzügyi teljesítőképességének. Így például a hitelfelvevő megalapozott választását segíti az is, hogy a hitelező a hitelszerződések mintaszövegét köteles az internetes honlapján hozzáférhetővé tenni.

A rendelkezés hiánypótló, mert bár a fogyasztók megtévesztése ellen eddig is volt szabályozás, de ebben a megközelítésben nemcsak a félreinformálás lett korlátozva, hanem a hitelfelvevők döntési hibáinak és nem racionális preferenciáinak tudatos kihasználása is kezelve lett.

\subsubsection{Egyéb szabályozások}

2015. január 1-től hatályba lépő úgynevezett adósságfék-szabályozás, alapvetően két fő pillérből áll. „A jövedelemarányos törlesztőrészlet-mutató az ügyfelek rendszeres, legális jövedelmének meghatározott arányában korlátozza az új hitel felvételekor maximálisan vállalható törlesztési terheket, és ezáltal mérsékli az eladósodást. A hitelfedezeti mutató (HFM) a fedezett hiteleknél (pl. jelzáloghitelek, gépjármúhitelek) a fedezetek értékének arányában korlátozza a felvehető hitelek nagyságát."³

Például a jövedelemarányos törlesztőrészlet mutató számításának módja:

Jövedelemarányos törlesztőrészlet mutató = havi adósságszolgálat/igazolt havi nettó jövedelem

Ez egyértelműen ösztönözheti a gazdaság fehéredését is, hiszen a jövőben csak a bevallott, legális jövedelem mellett lehet hitelt felvenni. Továbbá a gyakorlatban a hitelnyújtóknál a hosszú távú jövedelmezőség kárára előtérbe kerülhet a rövid távú jövedelmezőség. Ebben az esetben verseny indul a nagyobb piaci részesedésért, amit többek között az egyre kockázatosabb hitelfelvevők bevonásával lehet elérni. Ekkor a banki belső 'adósságfék'-szabályok lazulhatnak, emiatt szükség lehet egy külsőleg meghatározott, a kockázatnövelő versenyt leállító adósságfékre. Egy az egész rendszerre érvényes, a hitelfelvevők túlzott eladósodottságát korlátozó szabályozás tehát képes csökkenteni a szisztematikus kockázatok kialakulását.

\subsubsection{Teljes hiteldíj mutató plafon}

A fogyasztónak nyújtott hitelről szóló 2009. évi CLXII. törvény és egyes kapcsolódó törvények módosításáról szóló 2014. évi LXXVIII. törvény „A hitelszerződés feltételei és annak változása” alcíme a következővel egészült ki: „A hitelező (...) a fogyasztónak nem nyújthat olyan hitelt, amelynek teljes hiteldíj mutatója meghaladja a jegybanki alapkamat 24 százalékponttal növelt mértékét. Hitelkártya-szerződéshez vagy

\footnotetext{
${ }^{3}$ A jövedelemarányos törlesztőrészlet korlátozás adósságfékként védi a lakosságot. A Magyar Nemzeti Bank sajtóközleménye, Budapest, 2014. augusztus 27.
} 
fizetési számlához kapcsolódó, továbbá kézizálog fedezete mellett nyújtott hitelek esetében a teljes hiteldíj mutató nem haladhatja meg a jegybanki alapkamat 39 százalékponttal növelt mértékét." A finanszírozást igénybe vevők gyakran nem racionálisan mérik fel a jövőbeni törlesztési képességüket. A teljes hiteldíj mutató plafon szükséges, ha az előző fejezetekben ismertetett viselkedési aszimmetriák miatt a fogyasztók egy része túlbecsüli jövőbeni jövedelmét és elfogadna a jelenlegi helyzetéhez mérten nem racionális hiteldíjakat. Ezt a túlzott magabiztosságot igazolta Fischhoff - Slovic - Lichtenstein (1977), amikor arra a megállapításra jutott, hogy a szereplők várakozásai, amikben teljesen biztosnak érzik magukat, valójában csak 80 százalékos valószínúséggel válnak valóra. A téma szempontjából tehát a viselkedési pénzügyekben jelentkező túlzott optimizmus a jövőbeni jövedelemnövekedéssel kapcsolatban túlzott eladósodottsághoz vezethet, ha emiatt egy valójában túl magas adósságot vállal magára a fogyasztó.

\section{Következtetések}

A magánjog szerződéses szabadságának alapelvét kivételes esetben megtörni hivatott jogalkotói beavatkozás orvosolhatja a jelen felé torzított preferenciákat leíró modellekkel bemutatott aszimmetriákat. Ezekben az esetekben ugyanis az inkonzisztens időpreferencia, a túlzott önbizalom és jövőt illető optimista becslés következtében a fogyasztó nagy valószínűséggel olyan helyzetbe kerülhet, amikor a szerződéses egyensúly az ő hátrányára tolódik el. Ugyan a szabályozás indokolása és az irányadó joggyakorlat elsősorban az információs aszimmetriára hivatkozik, azonban alappal feltételezhető, hogy a felsorolt indokok önmagukban is alkalmasak a szerződéses egyenlőtlenség kialakulásához. Véleményünk szerint a szerződő felek között fennálló információs aszimmetria csak tovább gyengíti a fogyasztó szerződéses pozícióját, és egyértelműen nem jelenthető ki, hogy megfelelő információk, a szakmai ismeret és tapasztalat képes lehet semlegesíteni a torzított időpreferencia által gerjesztett döntést, mivel ez utóbbi elsősorban pszichológiai alapú, így jóval kisebb az esélye az objektív információkon alapuló, racionálisabb döntésnek.

A teljesség kedvéért meg kell állapítanunk azt is, hogy amennyiben a bankok olyan termékeket kínálnak a lakosságnak, amelyek kifejezetten a jelen felé torzult időpreferenciát használják ki, az a szerződéses egyensúly további romlásához vezet. Álláspontunk szerint a jelen felé torzult időpreferencia akár önmagában tekinthető olyan körülmények, amely indokolja a szerződéses szabadságba jogszabállyal történő beavatkozást. A viselkedési közgazdaságtan területén azonosított problémakörökre, különösen az időközi torzított döntési helyzetek elkerülésére, megakadályozására, az önkontrollproblémák felszámolására, az információs aszimmetria és a túlreagálások, a fogyasztói türelmetlenség kezelésére - álláspontunk szerint - megfelelő válaszokat adott a jogalkotó. A pénzügyi intézmények jogainak törvényi szintű korlátozása a fogyasztók érdekében (tájékoztatási kötelezettségek, szélesebb körű szerződéses 
jogok biztosítása), a fogyasztók megvédése saját maguktól (adósságfék szabályok) az információs aszimmetria visszaszorítása (erősödő tájékoztatási kötelezettség, kamat- és kamatfelár-mutatók bevezetése, hitelek kamatozási módszertanának előzetes meghatározása) mind olyan lépés, amely a viselkedési közgazdaságtan által feltárt anomáliák következtében kialakult hibás (irracionális) fogyasztói döntések visszaszorítására, valamint orvoslására alkalmas.

A feltárt problémák hatékony kezeléséhez azonban a sikeres szabályozáson túl szükség van a kellően hatékony felügyeletre is, amely érvényesíti a fogyasztók érdekében a jogszabályi előírásokat. Ezen a területen az elmúlt időszakban jelentős és trendszerű pozitív változás volt tapasztalható. A közismert nevén „fair bank” törvénycsomag új szabályrendszere alkalmas lehet a fogyasztói irracionalitást tükröző torzított időközi döntések, fogyasztói önkontroll problémára, valamint az alul- és túlreagálások kezelésére. A jogalkotó felismerte azt a társadalmi szükségletet, amely mögött a fogyasztó döntésekkel kapcsolatos egyenlőtlenségek, információs aszimmetria húzódik meg. Szabályozási szempontból azonban mindig kérdés, hogy a jogalkotó milyen mélyen, mekkora terjedelembe kíván beleavatkozni a felek magánjogi jogviszonyába. A túl enyhe beavatkozás nem képes kezelni a felek egyenlőtlenségének lehetséges káros következményeit, míg a túl széles, túl mély beavatkozás következtében a gazdasági szereplők viselkedése oly módon változhat meg, hogy az a piaci verseny torzításához, a gazdasági fejlődés nem kívánt és indokolatlan korlátozásához vezethet. De még a jól megalkotott szabályozás és a hatékony jogérvényesítés sem képes teljeskörüen kezelni a problémakört, mivel, ahogy láthattuk, a hibás, irracionális döntések kialakulásának háttere viselkedési jellegű, azaz az egyén, a fogyasztó viselkedését, pontosabban annak motivációját, mozgatórugóját kell megváltoztatni. A mögöttes motiváció, a gondolkodásmód megváltoztatása viszont elsősorban nem jogi eszközökkel, hanem oktatással, képzéssel és tájékoztatással valósítható meg. A jogi eszköztár mellé tehát az oktatási, képzési eszköztárat is fel kell sorakoztatni, mivel ténylegesen hatékony és teljeskörű megoldást mindezek együttes alkalmazása hozhat.

\section{Felhasznált irodalom}

Ausubel, L. M. (1999): Adverse Selection in the Credit Card Market. Working Paper, Department of Economics, University of Maryland.

Bánfi Zoltán (2013): Lehet-e túlzott mértékü a lakossági eladósodottság? Pénzügyi Szemle Online. http://www.penzugyiszemle.hu/vitaforum/lehet-e-tulzott-merteku-a-lakossagieladosodottsag. Letöltés ideje: 2016. június 9.

Barberis, N - Thaler, R (2003): A survey of behavioral finance. Handbook of the Economics of Finance. Elsevier, pp. 1053-1128. https://doi.org/10.1016/S1574-0102(03)01027-6. 
Bethlendi András (2015): Egy rossz termékfejlesztésből rendszerszintü piaci kudarc. A hazai lakossági deviza-jelzáloghitelezés. Hitelintézeti Szemle, 14. évf. 1. szám, március: 5-29.

Bölcskei Vanda (2009): Az intertemporális döntések viselkedés közgazdaságtani modelljeinek áttekintése. Közgazdasági Szemle LVI. évf., november: 1025-1040.

Camerer, C. - Babcock, L. - Loewenstein, G. - Thaler, R. (1997): Labor Supply of New York City Cab Drivers: One Day at a Time. Quarterly Journal of Economics, Vol. 112. May: 407-441. https://doi.org/10.1162/003355397555244.

Fischhoff, B. - Slovic, P. - Lichtenstein, S. (1977): Knowing with certainty: The appropriateness of extreme confidence. Journal of Experimental Psychology: Human Perception and Performance, 3: 552-564. https://doi.org/10.1037/0096-1523.3.4.552.

Fisher, I. (1930): The Theory of Interest. Macmillan, New York.

Kolozsi Pál Péter - Banai Ádám - Vonnák Balázs (2015): A lakossági deviza-jelzáloghitelek kivezetése: időzítés és keretrendszer. Hitelintézeti Szemle, 14. évf. 3. szám, szeptember: 60-87.

Koltay Gábor - Vincze János (2009): Fogyasztói döntések a viselkedési közgazdaságtan szemszögéből. Közgazdasági Szemle LVI. évf., június: 495-252.

Kovács Levente (2015): A pénzügyi kultúra kutatása és aktuális feladataink. Gazdaság és Pénzügy, 2. évf. 1. szám: 79-88.

Laibson, D. - Repetto, A. - Tobacman, J. (2003.): A Debt puzzle. In: Aghion, P. - Frydman, R. - Stiglitz, J. - Woodford, M. (szerk.): Knowledge, Information, and Expectations in Modern Economics. In Honor of Edmund S. Phelps. Princeton University Press, Princeton: 228-266.

Lentner Csaba - Szegedi Krisztina - Tatay Tibor (2015): A központi bankok társadalmi felelőssége. Vezetéstudomány, Budapest, 46. évf. (9-10): 35-47.

Lentner Csaba (2015): A lakossági devizahitelezés kialakulásának és konszolidációjának rendszertani vázlata. Pénzügyi Szemle 60(3): 305-318.

Loewenstein, G. - Prelec, D. (1992): Anomalies in Intertemporal Choice: Evidence and an Interpretation. The Quarterly Journal of Economics, Oxford University Press, vol. 107(2): 573-597. https://doi.org/10.2307/2118482.

Merton, R. (1969): Lifetime Portfolio Selection under Uncertainty: The Continuous -Time Case. Review of Economics and Statistics, augusztus: 247-257. https://doi.org/10.2307/1926560.

Nagy Benedek (2011): A kvázi-hiperbolikus diszkontálás alkalmazása az optimális szabadalmak elméletében. Szigma XLII. 1-2: 57-77. 
Nagy Márton (2015): Forintosítás - hogy is volt ez? https://www.mnb.hu/letoltes/15-0128-nagy-marton-istvan-forintositas-hogy-is-volt-ez.pdf. Letöltés ideje 2015. december 10.

Neszveda Gábor - Dezső Linda (2012): A kvázi- és általánositott hiperbolikus diszkontálás hosszú távon. Szigma XLIII. 3-4: 163-177.

Neumann, J. - Morgenstern, O. (1953): Theory of Games and Economic Behavior. Princeton, NJ. Princeton University Press.

Phelps, E. - Pollak, R. (1968): On Second-Best. National Saving and Game- Equilibrium Growth. Review of Economic Studies 35: 185-199. https://doi.org/10.2307/2296547.

Samuelsen, P. (1937): A Note on Measurement of Utility. Review of Economic Studies, Vol. 4. No. 2: 155-561. https://doi.org/10.2307/2967612.

Sebestyén Krisztián - Pintér Klára - Zsebő Béla (2011): Banki ajánlatok a viselkedési közgazdaságtan tükrében. Nemzetközi Bankárképző Központ. (A tanulmány a Gazdasági Versenyhivatal Versenykultúra Központ VKK 2/2010. számú pályázatára valósult meg.)

Stango, V. - Zinman, J. (2009): Exponential Growth Bias and Household Finance. Journal of Finance, American Finance Association, 64(6) December: 2807-2849. https://doi. org/10.1111/j.1540-6261.2009.01518.x.

Száz János (2015): A PKK-szindróma napjainkban: Széljegyzetek Kornai János legújabb gyújteményes kötetéhez. Magyar Tudomány 1: 75-86.

Tóth I. János - Árvai Zsófia: Likviditási korlát és fogyasztói türelmetlenség: A magyar háztartások fogyasztási és megtakarítási döntéseinek empirikus vizsgálata. Közgazdasági Szemle, 48. évf. 12. szám: 1009-1038.

Tversky, A. - Kahneman, D. (1974): Judgments and Uncertainty: Heuristics and Biases. Science, New Series, 185 (4157): 1124-1131. https://doi.org/10.1126/science.185.4157.1124. 